\title{
Influencing Factors:The Timeliness of Financial Reporting Submissions
}

\author{
Enni Savitri ${ }^{1}$, Andreas ${ }^{1}$, Raja Adri Satriawan Surya ${ }^{1}$ \\ ${ }^{1}$ Department of Accounting, Faculty of Economics and Business, Universitas Riau, Kampus Bina Widya Km. 12.5, \\ Simpang Baru, Tampan Pekanbaru, Riau, Indonesia \\ Correspondence: Enni Savitri, Department of Accounting, Faculty of Economics and Business, Universitas Riau, Kampus \\ Bina Widya Km. 12.5, Simpang Baru, Tampan Pekanbaru, Riau, Indonesia.
}

\author{
Received: February 11, 2019 \\ Accepted: March 5, 2019 Online Published: March 14, 2019 \\ doi:10.11114/bms.v5i1.4144 \\ URL: https://doi.org/10.11114/bms.v5i1.4144
}

\begin{abstract}
The purpose of this study was to examine the effects of profitability, leverage, firm size, outsider ownership, the reputation of the public accounting firm and financial risk on the timeliness of financial report submissions. This study used a sample of all the trade, services and investment companies listed in Indonesia Stock Exchange in 2014-2016. A total of 78 companies were examined. Multiple linear regression was used to test the hypotheses. Results showed that profitability, outsider ownership, the reputation of the public accounting firm and financial risk had significant effects on the timeliness of financial report submissions, but leverage and firm size did not have the effect. The originality of this paper is proven by that sample used of trade, service and investment companies and by using the measure of an auditor's reputation. Both of which had been studied earlier. The implications from this study for regulators is that regulations can be better determined to oversee and ensure a high standard from the financial reporting mechanism in the Indonesia Stock Exchange.
\end{abstract}

Keywords: profitability, leverage, firm size, outsider ownership, reputation of the audit firm, financial distress

\section{Introduction}

Companies need actual information in running a business. Actual information can provide accurate information relevant to current business conditions. Information is said to be relevant if the information can make a difference in making a decision. The most important information in the field of finance for a business is information in the form of financial statements or reports. The financial report is the final stage of the accounting process and plays an important role in measuring and evaluating the performance of a company. Financial statements contain records of business activities carried out by an entity within a certain period (Vuran dan Burcu, 2013). Companies in Indonesia, especially companies that are public entities, are required to prepare financial statements for each period. According to the Indonesian Association Accountants (IIA, 2013), the purposes of financial reports are to provide information on the financial position, financial performance, and cash flow. This report is useful for most report users in making economic decisions. Financial reports also have an important role as a means of communication between business people (Mannan et al., 2017).

Currently companies that are registered as public companies are required to submit financial reports to the public. The capital market regulation No.29 / PJOK.04 / 2016 states that public companies must submit an annual report to the financial services authority (FSA) no later than the end of the fourth month after the end of the financial year. The Indonesia Stock Exchange (IDX) hand out sanctions to public companies for the late submission of audited financial reports beyond the prescribed time limit. The regulation shows the intention of the FSA and IDX in cracking down on all companies that are late in submitting their financial reports. This is enforced to maintain the compliance of the listed companies, for the companies must fulfill the securities listing provisions and ensure information is disclosed to the public. This disclosure creates orderly, fair and efficient trade. All of these regulations are designed to ensure companies submit financial reports under the applicable regulations. The FSA at this time has determined there are still many companies that are not disciplined in their implementation of the regulations. The fact is there are still companies that are late in submitting their financial reports.

The purpose of this study was to analyze the effect of profitability, leverage, the size of the company, outsider ownership, public accounting firms reputation and financial risk on the timely submission of financial reports. Results showed that profitability, outsider ownership, the reputation of the public accounting firm and financial risk had significant effects on the timeliness of financial report submissions, but leverage and firm size did not have an effect. The results of this study will help identify and provide information about factors that influence the timeliness of financial reporting submissions 
and this has great implications for financial statement analysts, company management practitioners, investors and creditors. This will help regulators to provide information about the impact of regulations from the deadline for publishing annual financial statement.

\subsection{Conceptual Framework}

Agency theory assumes that all individuals act on their behalf (Jensen \& Meckling, 1976). Shareholders as principal parties are assumed only to be interested in increasing financial results or their investment in the company while it is assumed that the agents receive satisfaction in the form of financial compensation and the conditions that accompany the relationship (Alzoubi, 2016).

Signaling theory uses asymmetric information between companies and outsiders. Management personnel know more about the company's prospects and future opportunities than outside parties (investors). Information asymmetry will occur if management does not fully convey all information that can affect the company's value to the capital market (Bergh et al., 2014). To avoid asymmetric information, companies must provide information as a signal to investors. Asymmetrical information needs to be minimized, so public companies must give the company financial information in a transparent manner to investors (Saqer, 2015).

Timeliness implies that financial statements should be presented at a specific time interval and so explains changes in companies listed on the Stock Exchange which might affect information investors' use in making predictions and decisions (Puasa et al. 2014). Emeh and Appah (2013) showed that financial information users must be able to obtain the information they need at the right time especially if they are in a position of making or anticipating decisions. In this context, the timing of the information is as important as the content for the users of financial information. Information users regard financial reporting time as an important factor of accounting information (Ismail and Roy, 2015).

Profitability is one indicator of the company's success to generate profits. When a company's profitability increases the company's ability to generate profits is higher. Profitability is the ability of a company to create profits in the areas of sales, assets and share capital. Profitability is the net result of a series of policies and decisions (Brigham and Houston, 2014). Profitability is often used as a benchmark by investors and creditors in assessing whether a company is healthy or not (Al Daoud et al., 2014).

According to Niswonger (2008), leverage ratios measure the level of corporate assets that have been financed by the use of debt. The high ratio of debt to equity reflects the high risk of the company. This high risk indicates the possibility that the company cannot pay-off it's obligations or debts in the form of principal or interest payments (Putri, 2015).

Company size can be measured from several aspects. It can be based on the total assets value, total sales, market capitalization, number of workers, and so on (Niresh and Velnampy, 2014). The greater the assets of a company, the greater is the invested capital, the greater the total sales of a company, the more money will be turned-over and the larger the market capitalization and the greater the company will be known by the public (Ika and Ghazali, 2012).

Ownership structures are very important in determining company value. There are two aspects of ownership that need to be considered, namely ownership by an outside party and ownership by an internal party. The share ownership structure that is owned by an outside party usually has a percentage of ownership of more than $50 \%$, so that the owner of the company from outside the company has great power in influencing the conditions and results of the company's work (Zaitul, 2010).

Public Accounting Firms are institutions that have permission from the Finance Ministry to be avenues for public accountants to carry out their work. A large and well-reputed public accounting firm is usually indicated by Public Accounting Firms (PAF) that is affiliated with a universal accounting firm known as the Big Four Worldwide Accounting Firm (Big 4). Large public accounting firms are often referred to as having a better reputation in public opinion. This is because compared to small public accounting firms; large public accounting firms accountants normally have to behave more ethically (Ika and Ghazali, 2012).

A company is said to experience financial risk if the company has difficulty closing or fulfilling obligations to the company, it begins with minor difficulties to more serious difficulties. Ross (2010) asserts that financial risk could lead to financial distress if the company is unable to manage it. Financial risk is related to the ability of the firm in meeting all its obligation to the external parties in the form of debt. The level of financial risk can be seen from the company's level of leverage. The higher the leverage ratio, the higher the financial risk of the company and thus the higher the potential for facing financial distress.

\subsection{Hypotheses Development}

\subsubsection{Effect of Profitability on the Timeliness of Financial Report Submissions}

Profitability shows the successfulness of a company to make a profit. Profit is good news for a company. A company will 
not delay in delivering information that contains good news. Companies that can generate profits will tend to be timelier in the delivery of financial statements when compared to companies that report losses. Profits are good news for companies, so companies tend not to delay reporting on financial information. Studies by Sanjaya and Ni Gusti (2016) and Mannan et al. (2017) showed that profitability affects the timeliness of financial report submission.

Referring to the description above, the hypothesis is stated as follows.

$\mathrm{H}_{1}$ : Profitability affects the timeliness of financial report submissions

\subsubsection{The Effect of Leverage on the Timeliness of Financial Report Submissions}

According to Putri (2015), leverage ratios measure the level of corporate assets by the level of debt incurred. Companies that have higher leverage are companies that depend on external loans to finance their assets. Financial difficulties are considered bad news and will affect the position of the company by the public. This gives a negative signal for investors and stops them from investing in stocks. High financial difficulties mean the company management urges auditors to find convincing evidence that the company's financial statements are free from material misstatement. This work requires a longer audit time. The extra length of time taken for the audit results in the company not being able to submit their financial reports on time. Previous researches conducted by Mannan et al. (2017), Sanjaya and Ni Gusti (2016), and Dogan et al. (2007) showed that leverage affects the timeliness of submitting financial reports.

Referring to the description above, the hypothesis to be tested is stated as follows.

$\mathrm{H}_{2}$ : Leverage affects the timeliness of financial report submissions

\subsubsection{Effect of Company Size on Timeliness of Financial Report Submissions}

Firm size indirectly determines the ability of a company to produce profits. In Signalling theory, the size of a company can provide a good signal to investors. Companies that have a large size tend to maintain their image and comply with regulations, so investors receive a signal that the company's performance is indirectly considered good. According to Putri (2015), large companies are more consistently on time than small companies to submit their financial reports. This is because large companies tend to be more noticed by the public. Previous research was conducted by Niresh and Velnampy (2014), Sanjaya and Ni Gusti (2016), and Mannan et al. (2017). Referring to the description above, the hypothesis is stated as follows

$\mathrm{H}_{3}$ : Company size affects the timeliness of financial report submissions

\subsubsection{Effect of Outsider Ownership on the Timeliness of Financial Report Submissions}

Mannan et al. 2017, states that external stakeholders are elements that are beyond the control of the company (uncontrollable). Outsider ownership affects the timeliness of the submission of financial reports. Ownership from outside parties has a great power to put pressure on the management to present information promptly. Companies with a large proportion of public ownership tend to be on time in their financial reporting. Previous research was conducted by Niresh and Velnampy (2014) and Sanjaya and Ni Gusti (2016)

Referring to the description above, the hypothesis is stated as follows

$\mathrm{H}_{4}$ : Outsider ownership affects the timeliness of financial report submissions

\subsubsection{Effect of the Reputation of a Public Accounting Firm on the Timeliness of Financial Report Submissions}

A financial report or information about the company's performance must be presented accurately and reliably. Consequently the company needs the services of a public accounting firm (PAF). PAF conducts an audit of the company's financial statements. Companies that are audited by a reputable PAF are considered capable of providing reliable audit results. Mannan et al. (2017) states that the use of a large accounting firm will affect the timeliness of submitting financial reports. PAF's will always maintain their reputation to the public. PAF's have auditors who are reliable and trained in carrying out audit work. PAF's are considered to be able to do audit work efficiently and effectively. Previous research conducted by Dogan et al. (2007) and Al-Juadi and Al-fifi (2016) show that the reputation of the PAF influences the timeliness of submitting financial reports.

Referring to the description above, the hypothesis is stated as follows

$\mathrm{H}_{5}$ : The reputation of the KAP influences the timeliness of financial report submissions

\subsubsection{Effect of Financial risk on the Timeliness of Financial Report Submissions}

Financial risk is associated with a situation a company experiences when having difficulty in meeting or paying off their financial obligations. To avoid producing a report of poor quality, companies often try to fix the company's financial statements. The process of improving financial reports requires more time thus causing a delay in the delivery of financial reports. Companies that experience increased financial risk will request more of the auditor's attention when auditing 
financial statements. They request more time is taken to find out what happened within the company. This causes the submission timing of the company's financial reports to be delayed. In regard to Agency theory, companies that experience increased financial risk would encourage the management to use bonding costs which is one of the agency costs. This is done to regain the trust of the principal party in regard to the performance of management with a guarantee that the financial reports were audited by a public accounting firm. These costs will be even greater if there is a delay in the completion of the audit. The high bonding cost results in an inefficient agency that brings doubt on the performance of management and thus has an impact on the delivery of the financial reports. As revealed by Rachmawati (2008), financial distress affects the timeliness of the publication of financial statements. Companies that experience financial difficulties tend to be slow in submitting their financial reports.

Referring to the description above, the hypothesis is stated as follows

$\mathrm{H}_{6}$ : Financial risk affects the timeliness of financial report submissions

\section{Method}

\subsection{Population and Sample}

Population used in this study was all the companies in the trade, services and investment sector listed on the Indonesia Stock Exchange in 2014-2016. The population in this study was 78 companies. The sampling technique used was purposive sampling. Because the research was conducted over three observation periods, the total sample size was 234 companies. Data analysis method used was logistic regression analysis because the dependent variable used dummy variables and the independent variable were a mixture of metric and non-metric variables.

\subsection{Variable Definition and Variable Measurement}

The timeliness of the submission of financial reports is information that can be helpful in decision-making. Decisionmakers range from prospective investors to investors and company management themselves. There is a need to access information at the right time to prevent losing the benefits of the information.

This variable is measured using a dummy variable with a category. For companies that had submitted their reports promptly (submission of the financial reports was less than 120 days after the end of the year or before the 30th April) were classed as Category 1. Companies that were not on time (submission of the financial reports were more than 120 days after the end of the year or after the 30th April) were classed as Category 0.

\subsubsection{Profitability $\left(\mathrm{X}_{1}\right)$}

Profitability is an indicator of a company's success (effectiveness of management) in generating profits (Brigham and Houston, 2014). This variable is measured using the ROA (Return on Assets) ratio.

\subsubsection{Leverage $\left(\mathrm{X}_{2}\right)$}

$$
\text { ROA }=\frac{\text { Net Profit }}{\text { Total assets }}
$$

Leverage is a capital structure owned by a company, where leverage is used to determine the extent to which a company uses debt to finance it. (Brigham and Houston, 2014). This variable is measured using total debt verses total assets.

\subsubsection{Company Size $\left(\mathrm{X}_{3}\right)$}

$$
\text { DER }=\frac{\text { Total liabilities }}{\text { Total equity }}
$$

The size of a company is a scale which can classify companies as large or small according to various criteria. It can be classified from the total value of assets, total sales, market capitalization, number of workers and so on (Jogiyanto, 2013: 282). This variable is measured using the logarithm of total assets.

Company Size $=$ Ln (Total Asset)

\subsubsection{Outsider Ownership $\left(\mathrm{X}_{4}\right)$}

Outsider ownership is capital owned by institutions or institutions within the company. Outsider ownership is proxied by OWN = outside party shares divided by the total shares (Sanjaya and Ni Gusti, 2016).

$$
\text { oWN }=\frac{\text { Outside Party Shares }}{\text { Total Shares }}
$$




\subsubsection{Public Accounting Firms Reputation $\left(\mathrm{X}_{5}\right)$}

Public Accounting Firms Reputation is a public accounting firm (PAF) that is trusted by the public or by companies. Usually, a public accounting firm has a good reputation or good name because the PAF has an affiliation with a large public accounting firm that is universally known. These are a part of the Big Four Worldwide Accounting Firms ("Big 4").

This variable is measured using dummy variables. Company categories that use the services of PAF affiliates with PAF Big 4 are given a dummy value of 1 and the category of companies that use services other than PAF affiliates with PAF Big 4 are given a dummy value of 0 (Putri, 2015).

\subsubsection{Financial Risk $\left(\mathrm{X}_{6}\right)$}

In this study, the study highlights financial risk in terms of the inability of assets to cover liabilities. Financial risk is proxied by the accounting insolvency indicator, that is when the total book value of the debts exceeds the total book value of the assets. This variable is measured by comparing long-term debt with total assets.

$$
\text { Accounting Insolvency }=\frac{\text { Long Term Debt }}{\text { Total Asset }}
$$

\section{Result}

\subsection{Descriptive Analysis}

Descriptive statistical analysis used in this study was used to provide an overview or description of the research variables in the form of frequency tables showing minimum values, maximum values, mean values, and standard deviations. The results of the descriptive analysis are shown in Table 1 below:

Table 1. Descriptive statistics of Variables $N=234$

\begin{tabular}{lllll}
\hline Variable & Minimum & Maximum & Mean & Std. Deviation \\
\hline $\begin{array}{l}\text { Accuracy of Delivery Time of } \\
\text { Financial Reports }\end{array}$ & 0 & 1 & 0.91 & 0.280 \\
Profitability & -0.68 & 0.61 & 0.0294 & 0.11507 \\
Leverage & -6.41 & 18.19 & 1.2830 & 2.16239 \\
Company Size & 12.72 & 29.75 & 22.9037 & 5.15831 \\
Outsider Ownership & 2.07 & 92.80 & 26.9973 & 18.21191 \\
Paf Reputation & 0 & 1 & 0.41 & 0.492 \\
Financial Risk & 0.00 & 1.56 & 0.1707 & 0.19620
\end{tabular}

The dependent variable in this study was the timeliness of financial report submissions. This variable was measured using a dummy variable. The average of the timeliness of financial report submissions was 0.91 which was obtained from the results of the descriptive statistics. The standard deviation value of timeliness of financial report submissions was 0.280.

The first independent variable in this study was profitability. The profitability ratio is calculated by dividing the amount of net income by the total assets. From the results of descriptive statistics, the average profitability was 0.0294 . The highest value was equal to 0.61 , and the lowest value was equal to -0.68 and the standard deviation value of profitability was 0.11507 .

The second independent variable in this study was leverage. The method of calculating leverage was by using the ratio of debt to equity ratio (DER) which is the total debt divided by the total equity. From the results of descriptive statistics, an average of 1.2830 was obtained. The highest value was 18.19 and the lowest value was -6.41 , and the standard deviation value is 2.16239 .

The third independent variable in this study was the size of the company. The method of calculating the company size ratio was by using the logarithm of total assets. From the results of descriptive statistics, an average of 22.9037 was obtained. The highest value of the company size was 29.75 , and the lowest value was 12.72 , and the standard deviation value was 5.15831 .

The fourth independent variable in this study was outsider ownership. This variable was measured based on the number of shares of public ownership. The results of descriptive statistics for outsider ownership showed an average value of 26.9973 with the highest value of 92.80 and the lowest value of 2.07 and the standard deviation value of 18.21191. 
The fifth independent variable in this study was the reputation of a PAF. The method of calculation was that this variable was measured using a dummy variable. The PAF has an average value of 0.41 and a standard deviation value of 0.492.

The sixth independent variable in this study was financial risk. This variable was measured by comparing the long-term debt with total assets. Descriptive statistical results of financial distress showed an average value of 0.1707 with the highest value of 1.56 and the lowest value of 0.00 and the standard deviation value of 0.19620 .

Results of regression coefficients are expressed in the following equation:

$$
\operatorname{Ln}(\mathrm{TL} / 1-\mathrm{TL})=-2,316.745+7.921 \mathrm{X}_{1}-1.741 \mathrm{X}_{2}-0.268 \mathrm{X}_{3}+0.375 \mathrm{X}_{4}+8.297 \mathrm{X}_{5}+2.101 \mathrm{X}_{6}+\varepsilon
$$

\subsection{Results of Multiple Regression Analysis}

The logistic regression model was used to test the hypotheses in this study and to examine the effects of profitability, leverage, company size, outsider ownership, PAF reputation, and financial distress on the timeliness of financial report submissions. The results of the logistic regression analysis can be seen in Table 2 as follows:

Table 2. Results of Regression Analysis

\begin{tabular}{llll}
\hline Variable & Standardized Coefficient & Standard Error & Sig. \\
\hline Profitability & 7.921 & 3.105 & 0.011 \\
Leverage & -1.741 & 1.095 & 0.112 \\
Company Size & -0.268 & 0.154 & 0.082 \\
Outsider Ownership & 0.375 & 0.161 & 0.019 \\
PAF Reputation & 8.297 & 2.520 & 0.001 \\
Financial risk & 2.101 & 0.847 & 0.013 \\
\hline
\end{tabular}

From the results of Table 2 above, profitability (ROA), outsider ownership (OWN), PAF reputation, and financial risk affects the timeliness of the submission of financial reports; this can be seen from the significant value which is less than 0.05. Whereas leverage (DER) and company size (SIZE) do not affect the timeliness of the submission of financial statements, this can be seen from the significant value which is a larger value of 0.05 .

\section{Discussion}

\subsection{Effects of Profitability on the Timeliness of Financial Report Submissions}

Profitability affects the timeliness of the submission of financial reports because profitability shows success for the company in generating profits. Profit is good news for companies. Thus, the company will not delay the delivery of information containing good news. Thus, companies that can generate high profits tend to be quicker to submit their financial reporting than companies that have small profits or suffer losses. Prompt financial reporting is also encouraged because management will not delay in delivering information regarding the company's profit to the principal parties because it deals with the financial compensation that will be received by the agent. It is also good news for the principal parties so the principal parties will respond well to the management for their good performance. It is most likely the principal parties will use the same agent again to manage the company.

This is according to research conducted by Saqer (2015), Sanjaya and Ni Gusti (2016), Mannan et al. (2017), McGee and Yuan (2012), Owusu and Ansah (2014) which shows that profitability affects the timeliness of the submission of financial reports. But is not in line with research conducted by Niresh and Velnampy (2014), Al-Juadi and Al-Afifi (2016), Ezat and Elmasry (2008) and Alkhatib and Marji (2012) which stated that profitability does not affect the timeliness of financial report submissions.

\subsection{The Influence of Leverage on the Timeliness of Financial Report Submissions}

Leverage does not have an effect on the timeliness of the submission of financial reports because leverage cannot be a guide in determining the extent of mandatory financial statement disclosures. This is due to policy differences between each company. Also, companies or agents that have cooperation with principal parties have an increasingly higher level of leverage as a sign of the greater use of debt by agents that could endanger the company. However, looking at the current economic conditions related to debt problems it is considered normal and is not considered a constraint in a company as long as there is a possibility of settlement, so the principal parties ignore the information about the debt. Companies do not consider leverage as something that will affect their public image so it can be concluded that leverage does not affect the timeliness of financial reporting.

This is consistent with the research conducted by Niresh and Velnampy (2014), Putri (2015), Al-Juadi and Al-Afifi (2016) who found that leverage did not affect the timeliness of the submission of financial reports. But it is not in line with the 
research conducted by Mannan et al. (2017), Sanjaya and Ni Gusti (2016), and Dogan et al. (2007) who showed different results, namely leverage affects the timeliness of the submission of financial reports.

\subsection{Effect of Company Size on the Timeliness of Financial Report Submissions}

The size of the company does not affect the timeliness of the submission of financial reports because the total assets owned by the company does not always have a significant influence. Large or small companies both want to maintain their reputation in the general public. To maintain this reputation, they always try to publish their financial statements on time. Companies with high total asset values do not necessarily deliver their financial statements on time, but companies that have small total assets are also not always late in submitting their financial reports to the public. When viewed in terms of agency theory which discusses the relationship between agents and principal parties, both large and small companies have the same obligation to provide information about the state of the company to the public promptly. It is important that financial reports are delivered to the public in a timely manner so the truthfulness of the financial reports can be trusted. This is because financial reports will be used as a basis for decision making by the public.

The results of this study are in line with the research of McGee and Yuan (2012), Dogan et al. (2007) who explained in their research that the size of the company did not affect the timeliness of the submission of financial reports. But it is not in line with research conducted by Niresh and Velnampy (2014), Sanjaya and Ni Gusti (2016), Mannan et al. (2017), and Al-Juadi and Al-Afifi (2016) Abdelsalam and El-Masry (2008), Ezat and Elmasry (2008) who stated that the size of the company influences the timeliness of the submission of financial statements.

\subsection{The Effect of Outsider Ownership on the Timeliness of Financial Report Submissions}

Outsider ownership affects the timeliness of the submission of financial reports. The results of this study relate to the agency theory where companies with a large proportion of outside parties (principal parties) will need information about the financial statements submitted by the agent before the information loses its benefit to the users of that information. The information is widely assessed by the public about the company's performance through published financial reports. Large outside ownership companies tend to have more supervision so that investors are assured that the company is being monitored and also ensures the company's management does not act as they wish and are under pressure to perform well. This is because external ownership has great power to put pressure on the management to present information promptly. Thus, companies with a large proportion of public ownership tend to be timely in financial reporting. The concentration of public ownership puts more pressure on the management of the companies by parties outside the company or shareholders and are timelier in submitting the company's annual financial reports. Shareholders from outside will want to be able to immediately find out information on developments and the condition of the company.

This is consistent with the research conducted by McGee and Yuan (2012), Niresh and Valnampy (2014) and Sanjaya and Ni Gusti (2016) which showed that outsider ownership affects the timeliness of the submission of financial reports. But it is not in line with the research conducted by Dogan et al. (2007) and Mannan et al. (2017) who stated that outsider ownership does not affect the timeliness of the submission of financial reports.

\subsection{The Effect of PAF Reputation's on the Timeliness of Financial Report Submissions}

A public accounting firm's (PAF's) reputation influences the timeliness of submitting financial reports. Companies which use PAF affiliated with the PAF "Big 4" to audit their company's financial statements, usually complete the audited financial reports promptly. PAF's that have a good reputation can provide accurate information and can guarantee the credibility of financial reports. Also, people tend to be more willing to trust information based on evidence from their work. PAF's known to have the affiliation with PAF "Big 4" universally prevail because PAF's who have a good reputation have staff or agents who are professional for they obey the rules. The staff or agents tend to maintain the image of the PAF itself so that it always keeps a good image and is always trustworthy. Companies using PAF services with a good reputation will submit financial reports promptly. In other words, the greater the reputation of the PAF, the faster the company will publish its financial statements to the IDX.

This is in agreement with the research results of Mannan et al. (2017), Dogan et al. (2007), Al-Juadi \& Al-Afifi (2016), Putri (2015) which showed that the reputation of PAF influences the timeliness of submitting financial statements. But it is not in line with the research conducted by Al-Juadi and Al-Afifi (2016) and Abdelsalam and Al-Masry (2008) which showed that the reputation of a PAF does not affect the timeliness of the submission of financial reports.

\subsection{Effect of Financial Risk on the Timeliness of Financial Report Submissions}

A company strives to give confidence to the principal parties for the performance carried out by the management by fixing financial statements that contain bad news. The process of improving financial statements requires more time than usual thus causing delays in the delivery of financial reports. Companies that experience financial distress will demand more time from the auditors to audit financial statements by needing more time to find out what really happened in the company. This causes the timing of the company's financial statements to be delayed. Companies with a high level of financial 
difficulty have a longer period before submitting financial reports. Companies that have a high level of leverage cannot report their finances promptly, because the company will try to improve the level of leverage and it will be one of the factors for why the company is late in submitting their financial reports.

The results of this study are consistent with the research conducted by Rachmawati (2008) who found that financial distress affected the timeliness of financial report publications. But it is not in line with the research conducted by Rahmat et al. (2009) who stated that financial distress did not affect the timeliness of financial reports submissions.

\section{Conclusion}

Based on the results of the research and the discussion presented above, the following conclusions can be drawn: Profitability affects the timeliness of financial report submissions. Leverage does not have an effect on the timeliness of financial report submissions. The size of the company does not affect the timeliness of financial report submissions. Outsider ownership affects the timeliness of financial report submissions. The reputation of the PAF influences the timeliness of financial report submissions. Financial risk affects the timeliness of submitting financial reports.

\section{Suggestions}

A suggestion for future research is to have a larger sample and longer research periods to obtain better results and use analytical tools in addition to multiple linear regression.

\section{References}

Abdelsalam, O., \& El-Masry, A. (2008). The Impact of Board Independence and Ownership Structure on the Timeliness of Corporate Internet Reporting Of Irish- Listed Companies. Managerial Finance, 34(12), 907-918. https://doi.org/10.1108/03074350810915842

AlDaoud, K. A, Ku-Ismail, K. N. I, \& Lode, N. A. (2014). The Timeliness of Financial Reporting Among Jordanian Companies: Do Company and Board Characteristics and Audit Opinion Matter?. Asian Social Science,10(3),191201. https://doi.org/10.5539/ass.v10n13p191

Al-Juadi, O., \& Al-Afifi, A. A. M. (2016). The Factors Affecting Timeliness of Corporate Financial Reporting: Empirical Evidence from the Palestinian and Amman Stock Exchange. International Journal of Management Sciences and Business Research, 5(10),123-135.

Alkhatib, K., \& Marji, Q. A. (2012). Audit Reports Timeliness Empirical Evidence From Jordan. Procedia-Social and Behavioral Sciences, 62, 1342-1349. https://doi.org/10.1016/j.sbspro.2012.09.229

Alzoubi, E. S. S. (2016). Ownership Structure and Earnings Management: Evidence From Jordan. International Journal of Accounting \& Information Management, 24(2), 135-161. https://doi.org/10.1108/IJAIM-06-2015-0031

Bergh, D. D., Brian, L. C., \& David, J. K. (2014). Signaling Theory and Equilibrium In Strategic Management Research: An Assessment And A Research Agenda. Journal of Management Studies, 51(8),1334-1360. https://doi.org/10.1111/joms.12097

Brigham, E. F, \& Joel, F. H. (2014). Fundamentals of Financial management. (11nd ed.). Jakarta: Salemba Empat Publisher.

Dogan, M., Coskun, E., \& Celik, O. (2007). Is Timing of Financial Reporting Related to Firm Performance? An Examination on Ise Listed Companies. International Research Journal of Finance and Economic, 12, 220-233.

Emeh, Y., \& Appah, E. (2013). Audit Committee and Timeliness of Financial Reports: Empirical Evidence from Nigeria. Journal of Economics and Sustainable Development, 4(20), 14-25. https://doi.org/10.1108/AJEMS-11-2016-0163

Ezat. A, \& El-Masry, A. (2008). The Impact of Corporate Governance on The Timeliness of Corporate Internet Reporting By Egyptian Listed Companies. Managerial Finance, 34(2), 848-867. https://doi.org/10.1108/03074350810915815

Financial Service Authority Regulation No.29/PJOK 04/2016, Regarding the Decision to Submit Periodic Financial Statements of Issuers or Public Companies.

Ika, S. R., \& Ghazali, N. A. M. (2012). Audit Committee Effectiveness and Timelines of Reporting Indonesia Evidence. Managerial Auditing Journal, 27(4), 403-424. https://doi.org/10.1108/02686901211217996

Indonesian Accountants Association. (2016). Financial Accounting Standards. Jakarta: Salemba Empat Publisher.

Ismail, K. N. I. K., \& Roy, C. (2015). The Timeliness Of Quarterly Financial Reports Of Companies In Malaysia. Asian Review of Accounting, 12(1), 1-18. https://doi.org/10.1108/eb060770 
Jensen \& Meckling. (1976). The Theory 0f The Firm: Managerial Behavior, Agency Cost, and Ownership Structure, Journal of Financial and Economics, 3, 305-360. https://doi.org/10.1016/0304-405X(76)90026-X

Jogiyanto, H. (2013). Portfolio Theory and Investment Analysis. (8th ed.). Yogyakarta: BPFE Publisher.

Mannan, A., Hanafi, K., \& Usman, A. (2017). Company Size, Profitability, and Auditor Opinion Influence to Audit Report Lag and a Registered Manufacturing Company in Indonesia Stock Exchange. International Journal of Applied Business and Economic Research, 15(19), 353-367.

McGee, R. W., \& Yuan, X. (2012). Corporate Governance and The Timeliness of Financial Reporting: A Comparative Study of the People's Republic of China. The USA and The European. Union Journal of Asia Business Studies, 6(1), 5-16. https://doi.org/10.1108/15587891211190679

Niresh, J. A., \& Velnampy, T. (2014). Firm Size and Profitability: A Study of Listed Manufacturing Firms in Sri Lanka. International Journal of Business and Management, 9(4), 57-64. https://doi.org/10.5539/ijbm.v9n4p57

Niswonger, R. D. W. (2008). Principles of Accounting. (19 ${ }^{\text {th }}$ ed.). Jakarta: Erlangga Publisher.

Owusu-Ansah, S. (2014). Timeliness Of Corporate Financial Reporting In Emerging Capital Markets: Empirical Evidence From The Zimbabwe Stock Exchange. Accounting and Business Research, 30(3), 241-254. https://doi.org/10.1080/00014788.2000.9728939

Puasa, S., Mohd, F. M. S., \& Azlina, A. (2014). Audit Committee and Timeliness of Financial Reporting: Malaysian Public Listed Companies. Middle-East. Journal of Scientific Research, 22(2), 162-175.

Putri, A. I., \& Bambang, S. (2015). Various Factors Affecting Timeliness of Financial Reporting. Journal of Accounting Science and Research, 4(9), 1-8.

Rachmawati, S. (2008). The Influence of Internal FactorS and External Company Against Audit Report Lag and Timeliness. Journal of Accounting and Finance, 10(1), 1-10.

Rahmat. M. M, Iskandar, T, \& Saleh, N. M. (2009). Audit Committee Characteristics in Financial Distressed and NonDistressed Company. Management Auditing Journal, 24(7), 624-638. https://doi.org/10.1108/02686900910975350

Ross et al. (2010). Fundamental of Corporate Finance. (9th ed.), New York: McGraw-Hill.

Sanjaya, I. M. D. M., \& Ni-Gusti, P. W. (2016). Analysis of Factors Affecting Timeliness of Financial Reporting on Manufacturing Companies Listed on Indonesia Stocks Exchange. Journal of Accounting Udayana University, 15(1), $17-26$.

Saqer, S., \& Yousef, AL-Tahat. (2015). Timeliness of Audited Financial Reports Of Jordanian Listed Companies. IPASJ International Journal of Management (IIJM). Jerash University, Jordan.

Vuran, B., \& Burcu, A. (2013). Is Timeliness of Corporate Financial Reporting Related to Accounting Variables? Evidence From Istanbul Stock Exchange. International Journal of Business and Social Science, 4(6), 58-70.

Zaitul. (2010). Board of Directors, Audit Committee, Auditor Characteristics and the Timelines of Financial Reporting in Listed Companies in Indonesia. Doctoral Dissertation. College of Business. University Utara Malaysia.

\section{Copyrights}

Copyright for this article is retained by the author(s), with first publication rights granted to the journal.

This is an open-access article distributed under the terms and conditions of the Creative Commons Attribution license which permits unrestricted use, distribution, and reproduction in any medium, provided the original work is properly cited. 